\title{
De Jure Adoption and De Facto Implementation of FV Accounting in China ${ }^{1}$
}

(Chapter for book A Routledge Companion on Accounting in Asia, edited by Prof. Zhijun Lin)

\author{
Guoqiang Hu, Business School, Tianjin University of Finance and Economics \\ Bing Huang, Business School, Xiangtan University \\ Jason Xiao, Business School, Cardiff University (email: Xiao@cardiff.ac.uk) \\ Qin Xu, Business School, University of International Business and Economics \\ Dehui Yu, Management School, China Women’s University
}

\begin{abstract}
This study examines the extent of fair value accounting (FVA) adoption in China's thirty-eight new Enterprise Accounting Standards (EASs) in 2006, effective from 2007 and its implementation in practice by China's listed firms. Among the thirty-eight EASs, more than twenty-three standards require or permit FVA for initial measurement, subsequent measurement, and impairment recognition, and disclosures. However, there are four different forms of adoption across standards: mandatory, partially mandatory, conditionally mandatory, and voluntary. Further, this study empirically investigates the implementation of FVA in practice using hand-collected data on fair value (FV) measurement and disclosure from the annual reports of twenty-seven financial and 120 non-financial firms for the period of 2007 to 2011. We find that (1) the sample firms complied well with the mandatory or partially mandatory requirements of EASs to use FV in the measurement of assets and liabilities, but the quality of their FV information disclosure in the notes to financial statements was very low; (2) they were less likely to recognize impairment losses on intangible assets or goodwill than on fixed assets; (3) they were less likely to engage in transactions with conditionally mandatory requirements of FV adoption and if they had such transactions, they did not prefer FV measurement; and (4) few sample firms (especially non-financial firms) preferred the FV model for
\end{abstract}

\footnotetext{
1 This chapter is based on the project Fair Value Accounting in China led by Jason Xiao, sponsored by the ICAEW Charitable Trusts (project number: 5-444). The authors, all of whom are members of the project team, would like to thank ICAEW Charitable Trusts for financial support. Guoqiang Hu and Jason Xiao also acknowledge financial support from the National Natural Science Foundation of China (71502122).
} 
subsequent measurement of investment property, and the quality of the adopters' FV information disclosure was low. In addition, the sample firms tended to use external asset appraisers to estimate the FV of non-financial assets or liabilities. In contrast, most firms used quoted prices of identical assets or liabilities in the active markets or the appraisal value from asset appraisers as the FV of financial assets or liabilities. Finally, we find that the impact of FVA implementation in FI on financial statements was more significant for sample financial firms than that for sample non-financial firms during 2007 to 2011.. These results enhance our understanding of de facto FVA implementation in an emerging economy and have important policy implications for standards-setters and regulators of listed firms.

Keywords: Fair value accounting; China; Accounting standards; Convergence

\section{Introduction}

This study aims to examine the extent of fair value accounting (FVA) adoption in new Chinese Enterprise Accounting Standards (EASs) issued in 2006, and its implementation in China' listed firms in practice. Following the study of Peng and Bewley (2009), we use the term "adoption" to refer to the extent to which FVA is adopted in the 2006 EASs (i.e., de jure adoption), and the term "implementation" to refer to the extent which the adopted FVA in the 2006 EASs have been effectively implemented (i.e., de facto implementation).

This study is motivated by two reasons. First, the International Accounting Standards Board (IASB) is committed to develop International Financial Reporting Standards (IFRS) that bring transparency, accountability and efficiency to financial markets around the world and to work with national standards setters to achieve convergence. As a result, more than 100 jurisdictions so far have required or permitted the use of IFRS for public firms. This growing use of IFRS has prompted concerns and debates on the applicability of IFRS to emerging economics (e.g., Samaha and Khlif, 2016; Ebrahim and Fattah, 2015; Peng et al., 2013; He et al., 2012; Albu and Albu, 2012; Boolaky, 2010), given the fact that IFRS are based on a developed-economy perspective (Peng and Bewley, 2009). Following the international trend, China has also adopted IFRS by issuing a new set of EASs in 2006. As the world's largest emerging economy, China provides an important setting to gain a deep insight into IFRS implementation by examining the adoption and implementation of FVA.

Second, we focus on the adoption and implementation of FVA because it is a key feature of the 
2006 EASs and a fundamental change in China's accounting practice (Deloitte Touche Tohmatsu, 2006), but there is little empirical evidence on their implementation in practice. Recently, several practitioner speakers at the ICAEW's 2011 information for Better Markets Conference, e.g., Harrington (2011), Harris (2011), and Wallace (2011), identified numerous FVA implementation problems, including the complexity of IASB's fair value (FV) standards, the need for separate standards for banks and insurance firms, the need for separate standards for non-financial firms, the impractical FV standards guidance, the difficulties in maintaining consistency in valuing different and complex financial instruments, the problem of earnings volatility created by using FV measurement, and the large amount of FV related disclosures and the high cost involved in preparing them. There may be similar or more severe problems in emerging economics. However, little study has been undertaken of such implementation problems (Laux and Leuz, 2009).

Based on the setting of China, a stream of recent studies empirically investigates the economic consequences of FVA adoption. For example, He et al. (2012) documents several unintended effects of mandatory IFRS adoption in China by focusing on FVA adoption. Lijing and Li (2010) find evidence on the relevance of FV measurement for Chinese commercial banks. Qu and Zhang (2015) explore the suitability of FVA in China, and do not find evidence that FVA contributes to the improvement of value-relevance of earnings and book value due to IFRS convergence and the consequent application of FVA. Closely related to our study, Zhang et al. (2012) use a qualitative approach to explore the implementation of FVA in China as part of a global process of neoliberalization and financialization of political and economic systems, and argue that FVA institutionalizes a technical commitment to the ideals of neoliberalism. Zhang et al. (2012) argue that the practice of FVA is imbued with assumptions about the state and the market that have little bearing on the realities of Chinese capital markets. Peng and Bewley (2010) investigate the implementation of FVA in China using aggregated data in government reports, and their findings are based on preliminary outcomes two years after EAS implementation. Peng et al. (2013) provides a theory-based analysis of the process that eventually led to the acceptance of FVA in China. These studies suggest that China's institutions are in many respects incompatible with FVA, which thus causes unintended economic consequences (He et al., 2012). This study attempts to expand the literature by investigating the implementation issues of FVA in practice using hand-collected data from annual reports of China's listed firms.

To pursue our research objectives, this study first identifies the adoption of FVA in thirty-eight 
EASs issued in 2006 by the Ministry of Finance (MoF), the standards setter of China. We find that more than twenty-three of the thirty-eight EASs require or permit FVA. First is voluntary adoption of FVA for investment property. That is, firms can optionally use the cost model, or the FV model to subsequently measure investment property when there is an active property market and reliable market prices and other relevant information of identical or similar property can be continuously obtained. Second, use of FVA is partially mandatory. That is, firms are required to use FV measurement and disclose FV information under particular circumstances for debt restructurings, revenue, government grants, leases, and identifiable tangible and intangible assets acquired through business combinations not under common control. Third, FVA is conditionally mandatory for biological assets and exchanges of non-monetary assets. They should be measured using the cost model unless any well-established evidence indicates that the FV of relevant assets can be obtained in a reliable and continuous manner. Finally, FVA is mandatory for such assets or transactions as share-based payments, enterprise annuity fund, financial instruments, transfer of financial instruments, and the recoverable amounts in asset impairment tests.

Then, this study empirically investigates the implementation of FVA in practice by China's listed firms, using a hand-collected dataset on FV measurement and disclosure extracted from the annual reports of listed financial and non-financial firms for the period of 2007 to 2011. Analyzing this dataset, we obtain several findings. First, both financial and non-financial firms complied well with the mandatory or partially mandatory requirements of EASs in their use of FV to measure assets, liabilities, or transactions (ALTs), but they disclosed little FV information in the notes to financial statements. Meanwhile, while FV measurement is mandatorily required, the sample firms were more likely to recognize impairment losses on fixed assets than on intangible assets or goodwill probably because the FV of intangible assets and goodwill is more difficult to obtain and measure. Second, although firms are required to conditionally use FVA to measure ALTs, such as exchange of non-monetary assets, few firms had such ALTs and if they did have them, they preferred not to use FV to measure them. Third, few sample firms (especially non-financial firms) preferred the FV model for subsequent measurement of investment property even though they are allowed to optionally use it when reliable market prices and other relevant information of identical or similar assets can be continuously obtained. Even if they adopted FV measurement, the quality of their FV information disclosure was low. Fourth, the sample firms largely depended on the external asset appraisers to estimate the FV (Level 3 FV) of 
non-financial assets or liabilities. Some even directly used the carrying value to represent the FV of relevant assets or liabilities. In contrast, most firms used Level $1 \mathrm{FV}$ represented by quoted prices of identical assets or liabilities in the active markets or Level $3 \mathrm{FV}$ such as an appraisal value from asset appraisers as the FV of financial assets or liabilities. Moreover, the firms also disclosed more detailed FV information on financial assets or liabilities. Finally, the impact of FVA implementation on financial statements of sample non-financial firms was insignificant during 2007 to 2011 except for a few firms. In contrast, the financial impact of FVA implementation in measuring financial instruments was considerately more significant for financial firms.

Overall, these findings indicate that FVA is widely applied not only in EASs, but also in practice. However, the level of implementation of FVA for non-financial instruments by listed firms was low but it was relatively high for financial instruments. We believe that the results indicate important implications for standards setters and the regulators of listed firms.

The remainder of this study is organized as follows. Section 2 outlines the adoption of FVA in the 2006 EASs. Section 3 describes our data sources and research methods. In Sections 4 and 5, we analyze the extent of implementation of FVA by China's non-financial listed firms and financial listed firms, respectively. Section 6 concludes this study with a discussion of our findings and their policy implications.

\section{The adoption of FVA in China's accounting standards}

2.1 The development of FVA in China

The first adoption of FVA in China can be traced back to 1998 when "Enterprise Accounting Standard - Debt Restructurings" was released by the MoF. Before this, historical cost was the dominant measurement basis in Chinese accounting systems while FV was strictly prohibited. Since the reform and opening-up policy initiated in 1979, China's economy has experienced rapid development and integrated more fully with international markets. Shanghai Stock Exchange (SHSE) and Shenzhen Stock Exchange (SZSE) were established in 1990 and 1991 respectively. These developments presented challenges to the traditional accounting systems based purely on historical cost (Peng and Bewley, 2009). In order to meet the needs of economic development and bring Chinese accounting standards more into line with IFRS, the MoF successively issued ten accounting standards from 1997 to 2000. Among these standards, FVA was required in Debt Restructurings (1998), Investments (1998), 
and Non-Monetary Transactions (1999). For example, the debt restructurings standard defines FV as the amount for which an asset could be exchanged, or a liability settled, between knowledgeable, willing parties in an arm's length transaction. The standard further stipulates that assets surrendered or received by the debtors or creditors in debt restructurings should be measured at FV, and meanwhile, any gain or loss due to restructurings should be recorded as net income in the current period. Additionally, FVA was indirectly used in impairment tests of assets in 1998.

However, these three standards were hastily revised and their application of FVA was suspended in 2000 , only one year after the release of the non-monetary transactions standard and two years after the release of the debt restructurings and investment standards. The main reason for this abandonment was that many listed firms used FV for earnings management, and the inactive markets and a shortage of valuation experts made it difficult to measure FV (Feng, 2001). In a speech to A Symposium of the Issues on Accounting and Finance under the New Economic Environment in 2002, Feng (2003), an official of the MoF, observed that lacking active markets in China at present caused extreme difficulties for FVA adoption in practice; as the use of FV largely depends on the subjective judgment and estimates of accountants, the reliability of FV information was questioned, and FVA provided substantial room for enterprises to manipulate earnings. Indeed, Wang (2005) finds that the adoption of FVA in non-monetary transactions caused significant earnings manipulation, but the abuse of FV was promptly inhibited by the revised standard on non-monetary transactions where FV was replaced by carrying value. Dai et al. (2007) provide evidence on earnings management in impairment of assets.

Nonetheless, in the 2000 Chinese Enterprise Accounting System which entirely abandoned the use of FVA, the MoF further expanded the scope of asset impairment tests from only four types of asset (that is, inventories, accounts receivables, and short-term and long-term investments) to virtually all assets except cash. Despite the broader move away from FV, the use of asset impairment tests illustrates the continuing convergence of Chinese accounting standards with international ones (Peng et al., 2009).

As China entered WTO in 2001, the resulting increase in foreign direct investment and cross-border trade created a stronger demand for convergence with international standards. On November 8, 2005, China Accounting Standards Committee (EASC) representatives signed a convergence strategy agreement with IASB. Then, the MoF issued the 2006 EASs based on IFRS on February 15, 2006. The 2006 EASs consist of a revised conceptual framework and thirty-eight specific 
standards, with effect for listed firms from January 1, 2007, and for non-listed financial firms, central and local state-owned enterprises (SOEs) from January 1, 2008. Other enterprises were also encouraged to apply the 2006 EASs. A major feature of the 2006 EASs is that FV measurement or disclosure which was previously banned in the Enterprise Accounting System stipulated by the MoF in 2000 , is required or permitted in over twenty standards. The 2006 EASs covered almost all aspects of FVA, including initial measurement, subsequent measurement, impairment recognition, and disclosures.

Nevertheless, 'Considering the realistic situation of an emerging market and transition economy, the [2006] EASs mainly adopt historical cost accounting and set strict conditions for the application of FVA' (MoF, 2010). The restrictions or conditions are set out in specific standards. For example, the FV model is allowed for subsequent measurement of investment property and biological assets only when the FV can be continuously and reliably obtained. The 2006 EASs also prohibits the reversal of impairment losses of fixed assets, intangible assets, and other assets.

\subsection{The adoption of FVA in the 2006 EASs}

As noted above, FVA is required or permitted in over twenty standards of 2006 EASs. There are four forms of de jure adoption across standards, including voluntary, conditionally mandatory, partially mandatory, and mandatory adoption.

First, voluntary adoption of FVA is allowed. That is, a firm can optionally use FV to measure some assets or transactions. For example, a firm can optionally use the FV model for subsequent measurement when there is conclusive evidence that the FV of an investment property can be reliably determinable on a continuing basis (EAS 3 Investment Property). However, when the FV model is chosen, the firm is also required to disclose the basis and method used to determine the FV and the impact of FV changes on earnings.

Second, the adoption of FAV may be conditionally mandatory, that is, relevant assets or liabilities should be measured at FV when specified conditions are met. For example, when an exchange of non-monetary assets meet both of the following conditions, the cost of the asset received should be measured at FV plus any related taxes, and the difference between the FV used and the carrying amount of the asset given up should be recognized in profit or loss for the current period: (1) the exchange transaction has commercial substance and (2) the FV of either the asset received or the asset 
given up can be reliably measured (EAS 7 Exchange of non-monetary assets).

Third, adoption of FVA is partially mandatory. This means that a firm uses FV measurement for some transactions under particular circumstances. For instance, when a debt is repaid by a transfer of non-cash asset(s) to the creditor in a debt restructuring, the debtor should recognize the difference between the carrying amount of the debt and the fair value of the non-cash asset(s) transferred in profit or loss for the current period (EAS 12 Debt Restructurings). Similarly, an enterprise shall determine the cost of business combination at $\mathrm{FV}$ when the business combination does not involve enterprises under common control (EAS 20 Business Combinations).

Finally, mandatory adoption of FV requires a firm to use FV, rather than other measurements, to measure relevant assets or liabilities. For example, financial assets or liabilities shall be initially measured at FV according to EAS 22 Recognition and Measurement of Financial Instruments. Similarly, liquid financial products that are acquired in the operation of an enterprise annuity fund should be measured at FV on initial acquisition and on subsequent valuations (EAS 11 Enterprise Annuity Fund).

Table 1 charts the adoption of FVA in the thirty-eight specific EASs by 31 December 2013. Two new EASs issued by the MoF after 2013 are related to the adoption of FV accounting, but are not included in our analysis. The MoF released EAS 39 Fair Value Measurement in January 2014, which became effective on 1 July 2014 for entities adopting EASs. EAS 39 is based on IFRS 13 Fair Value Measurement, which standardizes the definition of FV, clarifies valuation techniques and the fair value hierarchy, and specifies the disclosures of relevant information of FV measurement. EAS 41 Disclosure of Interests in Other Entities issued by the MoF in March, 2014 stipulates that an entity that becomes an investment entity shall disclose the effect of the change of status on the financial statements for the reporting period, including the total amount of $\mathrm{FV}$, as of the date of change of status, of the subsidiaries that cease to be consolidated, and the total gain or loss related to the change of the total amount of FV. In addition, the MoF also released four revised accounting standards in 2014 that are related to FVA, that is, EAS 2 Long-term Equity Investment, EAS 9 Employee Benefits, EAS 30 Presentation of Financial Statements, and EAS 37 Presentation of Financial Instruments. However, the amendments do not affect the adoption of FVA in the four standards.

The overall adoption of FVA in EASs reported in Column (5) of Table 1 shows that twenty-three standards require or permit FV measurement or disclosure. Columns (1), (2), (3), and (4) indicate the 
extent of FV adoption in initial measurement, subsequent measurement, impairment tests, and disclosure, respectively.

Table 1 Adoption of FVA in the 2006 Enterprise Accounting Standards

\begin{tabular}{|c|c|c|c|c|c|}
\hline & (1) & (2) & (3) & (4) & (5) \\
\hline EASs No & $\begin{array}{c}\text { Initial } \\
\text { measurement }\end{array}$ & $\begin{array}{l}\text { Subsequent } \\
\text { measurement }\end{array}$ & $\begin{array}{l}\text { Impairment } \\
\text { tests }\end{array}$ & Disclosure & $\begin{array}{l}\text { Over } \\
\text {-all }\end{array}$ \\
\hline EAS 1 Inventories & PM & & & & Yes \\
\hline EAS 2 Long-term equity investments & PM & & M & & Yes \\
\hline EAS 3 Investment property & & $\mathrm{V}$ & $\mathrm{CM}$ & $\mathrm{CM}$ & Yes \\
\hline EAS 4 Fixed assets & PM & PM & M & PM & Yes \\
\hline EAS 5 Biological assets & PM & $\mathrm{CM}$ & M & & Yes \\
\hline EAS 6 Intangible assets & PM & PM & M & & Yes \\
\hline EAS 7 Exchange of non-monetary assets & $\mathrm{CM}$ & & & $\mathrm{CM}$ & Yes \\
\hline EAS 8 Impairment of assets & & & M & M & Yes \\
\hline EAS 10 Enterprise annuity fund & M & M & & M & Yes \\
\hline EAS 11 Share-based payment & M & M & & M & Yes \\
\hline EAS 12 Debt restructurings & PM & & & M & Yes \\
\hline EAS 14 Revenue & PM & & & & Yes \\
\hline EAS 16 Government grants & PM & & & & Yes \\
\hline EAS 20 Business combinations & PM & & & PM & Yes \\
\hline EAS 21 Leases & PM & & & PM & Yes \\
\hline $\begin{array}{l}\text { EAS } 22 \text { Recognition and measurement of financial } \\
\text { instruments }\end{array}$ & M & PM & M & PM & Yes \\
\hline EAS 23 Transfer of financial assets & M & M & & & Yes \\
\hline EAS 24 Hedging & M & M & & & Yes \\
\hline EAS 27 Extraction of petroleum and natural gas & & PM & PM & & Yes \\
\hline EAS 30 Presentation of financial statements & & & & M & Yes \\
\hline EAS 31 Cash flow statements & & & & M & Yes \\
\hline EAS 37 Presentation of financial instruments & & & & M & Yes \\
\hline $\begin{array}{l}\text { EAS } 38 \text { First-time adoption of EAS for Business } \\
\text { enterprises }\end{array}$ & M & & M & M & Yes \\
\hline Total (M/PM /CM /V) & $17(6 / 10 / 1 / 0)$ & $10(4 / 4 / 1 / 1)$ & $9(7 / 1 / 1 / 0)$ & $14(8 / 4 / 2 / 0)$ & 23 \\
\hline
\end{tabular}

Notes: M, PM, CM, and V indicate the four different levels of FVA adoption requirements across standards: mandatory, partially mandatory, conditionally mandatory, and voluntary.

\section{Methodology and Data}

To well capture the current situation of FVA implementation, we hand-collected data on FV measurement and disclosures form the annual reports of a sample of listed financial and non-financial firms. The process of collecting data began with the identification of the adoption of FVA in initial measurement, subsequent measurement, impairment tests, and disclosures by going through all the 
2006 EASs and related application guidance issued during 2006-2012. Then, we distinguished the four forms of FV adoption in specific 2006 EASs: mandatory, partially mandatory, conditionally mandatory, and voluntary, as shown in Table 1. Finally, we designed two checklists for picking up data from the annual reports of the sample firms. After discussion by members of the research team a few times and a trial data collection using 100 annual reports of five financial firms and fifteen non-financial firms for 2007-2011, the two checklists were finalized.

We randomly selected 120 non-financial firms from 2,415 listed A-share firms which were listed as of December 31, 2011 and obtained 600 firm-year observations for 2007-2011. The sampling process and the industry distribution of the sample are shown in Panels A and B of Table 2, respectively. As shown in Panel C, our sample of financial firms included all listed A-share financial firms (making up 135 firm-year observations) as of December 31, 2011, excluding financial firms listed after 2007 because we wanted all sample firms to fall into the same time period. The annual reports of all sample firms for the sampling period were downloaded from http://www.cninfo.com.cn/ on which listed firms publish their annual reports and other firm information as required by the China Securities Regulatory Commission (CSRC). From the annual reports, FV measurement and disclosure data were manually collected by one $\mathrm{PhD}$ student in accounting and three accounting lecturers in Chinese universities.

Table 2 Sample selection and distribution

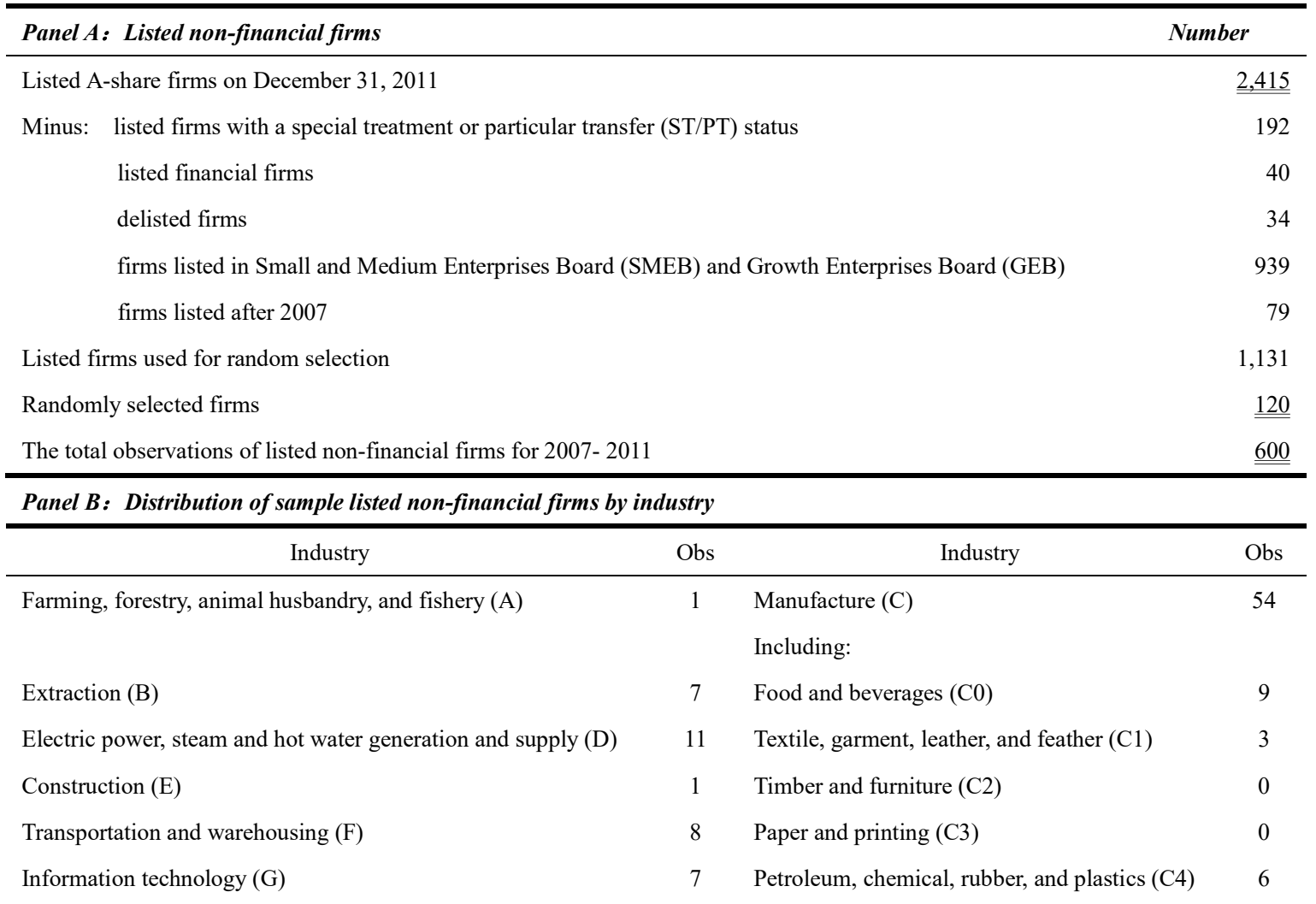




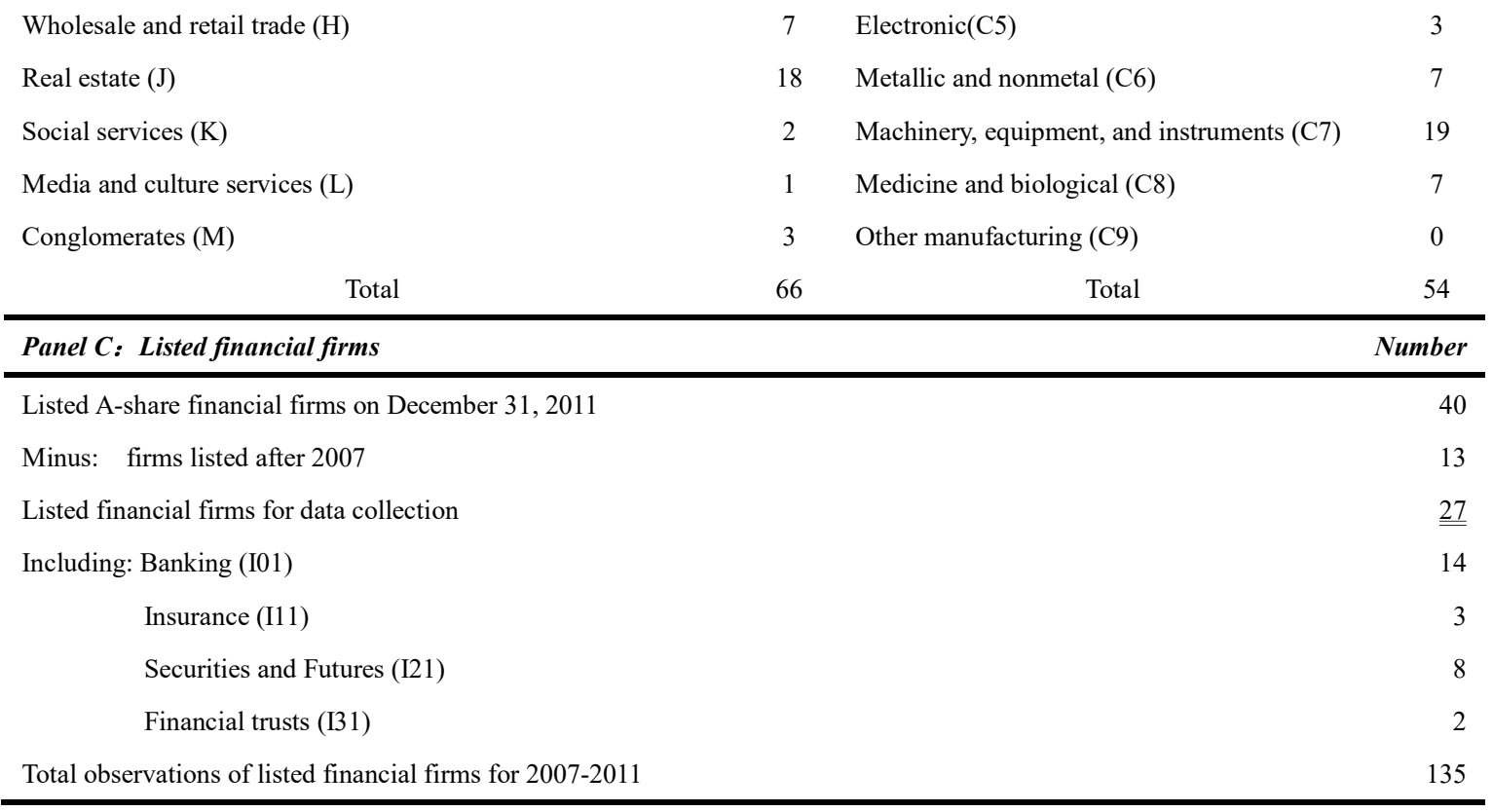

\section{Implementation of FVA in listed Chinese non-financial firms}

Based on the regulatory framework of FVA in China and hand-collected data from Chinese listed non-financial firms, this section first reports the extent of China's implementation of FVA in practice, including initial and subsequent measurement, impairment tests, and disclosure, in the first four parts. As FVA is widely adopted in EAS 22 Recognition and Measurement of Financial Instruments, EAS 23 Transfer of Financial Assets, EAS 24 Hedging, and EAS 37 Presentation of Financial Instruments, we focus on them in the fifth part of this section.

4.1 Use of FV for initial measurement

The current EASs prescribe different forms of requirements of FV use for initial measurement, including mandatory, partially mandatory, and conditionally mandatory. This section investigates how these requirements are implemented.

4.1.1 Implementation of the mandatory requirements of $\mathrm{FV}$ use for initial measurement

Apart from the financial instruments standards, three other standards require enterprises to use FV in initial measurement mandatorily, that is, EAS 10 Enterprise Annuity Fund, EAS 11 Share-Based Payment, and their relevant requirements in EAS 38 First-Time Adoption of Accounting Standards for Business Enterprises.

Table 3 reports the descriptive statistics on the implementation of mandatory requirements of FV use for initial measurement in the 600 non-financial firm-year observations. We find that fifty-six out 
of the 600 firm-year observations presented the amounts of annuity fund in the notes to financial statements, involving twenty-one firms. This suggests that these firms established enterprises annuity fund schemes and recognized annuity fund. Further, four out of the twenty-one firms disclosed that they established annuity fund schemes, but did not provide any detail about them. The level of disclosure was well below what is prescribed in the standards. According to EAS 10 Enterprises Annuity Fund, listed firms should disclose the following information in the notes: the kinds of investment, amounts, and methods for the recognition of the $\mathrm{FV}$; the proportion of each kind of investment to total investment; and, any other event that is likely to cause important influence on the investment value.

Table 3 also indicates that only seventeen out of the 600 non-financial firm-year observations experienced share-based payment, involving eight firms. On December 31, 2005, the CSRC issued "Administrative Regulations on the Effect of Stock Incentives of Listed Firms (trail implementation)", marking the beginning of a new era in China's system of equity-based compensation. By the end of 2011, 299 listed firms in China's A-share market issued draft equity incentive schemes, but few firms officially implemented them (that is, they were later cancelled or suspended for various reasons). Further, all seventeen observations used FV to initially measure share-based payment, and most of them chose the binomial model or the Black-Scholes option pricing model to identify the FV of share-based payment. However, few firms disclosed detailed information on how to estimate FV, such as assumptions and parameters for estimation.

Table 3 Implementation of mandatory FV requirements for initial measurement by non-financial firms

\begin{tabular}{llrr}
\hline & & $\begin{array}{c}\text { EAS 10 Enterprise } \\
\text { Annuity Fund }\end{array}$ & $\begin{array}{r}\text { EAS 11 Share-Based } \\
\text { Payment }\end{array}$ \\
\hline $\begin{array}{l}\text { No. of observations involving mandatory FV requirements for } \\
\text { initial measurement }\end{array}$ & 56 & 17 \\
{$[\%$ of 600 observations] } & Yes & {$[9.33]$} & {$[2.83]$} \\
\hline \multirow{2}{*}{$\begin{array}{l}\text { Whether use FV for } \\
\text { initial measurement }\end{array}$} & No & - & 17 \\
& Undisclosed & - & 0 \\
\hline \multirow{2}{*}{$\begin{array}{l}\text { Implementation by } \\
\text { the FV hierarchy }\end{array}$} & Level 1 & 56 & 0 \\
\hline & Level 3 & - & 2 \\
\end{tabular}

4.1.2 Implementation of partially mandatory requirements of $\mathrm{FV}$ use for initial 
measurement

The partially mandatory use of FV for initial measurement is applicable to the following cases: (1) the cost of assets invested by investors should be recognized as the initial value in accordance with the value as stipulated in the investment contract or agreement, but the FV of the assets should be initially recorded when the value stipulated in the investment contract or agreement is deemed to be unfair; and (2) for assets acquired through an exchange of non-monetary assets (EAS 7), debt restructurings (EAS 12), government grants (EAS 16), or business combinations (EAS 20), the FV of the assets should be recognized as the initial cost when these transactions use FV to measure the assets. The assets involving these transactions may include inventories, long-term equity investment, fixed assets, biological assets, and/or intangible assets, and these are reflected in EAS 1 Inventories, EAS 2 Long-Term Equity Investments, EAS 4 Fixed Assets, EAS 5 Biological Assets, and EAS 6 Intangible Assets. In addition, use of FV is also partially mandatory for initial measurement of some special transactions as prescribed in EAS 4 Fixed Assets and EAS 14 Revenue. For example, EAS 4 Fixed Assets stipulates that if a certain payment is made for purchasing several fixed assets not priced separately, the cost of each fixed assets should be recognized by allocating the payment according to the proportion of FV of each fixed asset to the total cost of all assets acquired.

Table 4 reports the descriptive statistics on the implementation of partially mandatory requirements of the use of $\mathrm{FV}$ in initial measurement by non-financial firms. The results show that twenty-nine out of the 600 firm-year observations involved the partially mandatory requirements of FV use for initial measurement of inventories, which was largely because of business combinations (twenty-five observations). Further, fourteen out of the twenty-nine sample observations used FV, twelve used carrying value, to measure the value of inventories, and three did not disclose relevant information. Among the fourteen non-financial firm-year observations, eight used Level 3 FV by employing asset appraisers to estimate the FV of inventories, but six did not disclose this information.

Eleven non-financial firm-year observations reported how they dealt with initial measurement of long-term equity investment when required to use FV measurement by EAS 2 Long-Term Equity Investment. $^{2}$ Five out of the eleven observations used the appraisal value as the FV of long-term equity investment, four did not adopt FV measurement, but used the carrying value instead, and two did not

2 This does not include long-term equity investment due to business combinations not under common control, which is dealt with in EAS 20 Business Combinations. 
disclose this information. Noticed that this standard is closely related to EAS 20 Business Combinations, which stipulates that for a business combination not under common control, the combination cost should be the acquisition-date FV of the assets paid, the liabilities incurred or assumed and the equity securities issued by the acquirer in exchange for the control over the acquiree; and, the acquirer should recognize goodwill as of the acquisition date measured as the positive balance of the combination cost over the FV of the net of the identifiable assets it obtains from the acquiree. Table 4 shows that seventy-nine out of the 600 observations used FV to initially measure the long-term equity investment due to business combinations not under common control. In particular, fifty-nine out of the seventy-nine observations used the appraisal value as Level 3 FV to initially measure the long-term equity investment, while nineteen directly used the carrying value to represent the FV.

Table 4 also shows that forty-two out of the 600 non-financial firm-year observations involved partially mandatory requirements of FV use for initial measurement of fixed assets, which was largely because of the business combinations not under common control, which made up thirty-seven observations. Twenty-eight out of the forty-two observations used FV to initially measure fixed assets, most of which relied on an appraisal value (Level $3 \mathrm{FV}$ ), and fourteen of which directly used the carrying value. Few firms disclosed relevant information on how to identify the FV of fixed assets. Similar results can be found for the implementation of partially mandatory requirements of using FV to measure intangible assets. Table 4 shows that thirty-four of the 600 observations involved the partially mandatory requirements of FV use for initial measurement of intangible assets, largely due to business combinations not under common control. Most of them adopted the FV measurement, in particular Level 3 FV by using an appraisal value. Two observations accepted intangible assets from government grants but did not disclose any relevant information.

Concerning the use of EAS 12 Debt Restructurings, Table 4 shows that ninety-nine out of the 600 observations experienced debt restructurings in our sample period, but few of them (only nine observations) used FV for the initially measurement of related assets or liabilities. Sixty-one observations only disclosed the total amount of the gains or losses on debt restructurings without revealing any further details. The nine observations using the FV measurement relied on an appraisal value. We also find that the partially mandatory requirements of FV use for initial measurement of lease transactions were applicable to twenty-one out of the 600 observations, but only two stated in the notes that they used the FV of the leased assets and the present value of the minimum lease payments 
to initially measure the leased asset, and did not disclose detailed information. Four observations used the carrying value as the FV. Most of the twenty-one observations did not disclose any information on whether the firms used FV measurement or how to identify the FV. In addition, none of the sample firms involved in the application FVA to biological assets, had government grant transactions, or used FV to recognize revenue. 
Table 4 Implementation of partially mandatory FV requirements for initial measurement by non-financial firms

\begin{tabular}{|c|c|c|c|c|c|c|c|c|c|c|}
\hline & $\begin{array}{c}\text { EAS } 1 \\
\text { Inventory }\end{array}$ & $\begin{array}{c}\text { EAS } 2 \\
\text { Long-term } \\
\text { Equity } \\
\text { Investment }\end{array}$ & $\begin{array}{c}\text { EAS } 20 \\
\text { Business } \\
\text { Combinations }\end{array}$ & $\begin{array}{l}\text { EAS } 4 \\
\text { Fixed } \\
\text { Assets }\end{array}$ & $\begin{array}{c}\text { EAS } 5 \\
\text { Biological } \\
\text { Assets }\end{array}$ & $\begin{array}{c}\text { EAS } 6 \\
\text { Intangible } \\
\text { Assets }\end{array}$ & $\begin{array}{l}\text { EAS } 12 \\
\text { Debt } \\
\text { Restructur- } \\
\quad \text { ings }\end{array}$ & $\begin{array}{l}\text { EAS } 14 \\
\text { Revenue }\end{array}$ & $\begin{array}{c}\text { EAS } 16 \\
\text { Government } \\
\text { Grants }\end{array}$ & $\begin{array}{l}\text { EAS } 21 \\
\text { Leases }\end{array}$ \\
\hline \multicolumn{11}{|l|}{ Panel A: Whether used the standard } \\
\hline $\begin{array}{l}\text { No. of observations involving partially } \\
\text { mandatory FV requirements for initial } \\
\text { measurement } \\
\text { [\% of } 600 \text { observations] }\end{array}$ & {$[4.83]$} & {$[1.83]$} & {$[13.17]$} & {$[7.00]$} & {$[0]$} & {$[5.67]$} & {$[16.5]$} & {$[0]$} & {$[0]$} & [3.50] \\
\hline \multicolumn{11}{|l|}{ Panel B: The way the asset acquired } \\
\hline Invested by investors & 0 & 0 & 2 & 0 & 0 & 3 & - & - & - & - \\
\hline Exchange of non-monetary assets & 0 & 3 & 0 & 1 & 0 & 2 & - & & - & - \\
\hline Debt restructurings & 2 & 4 & 0 & 1 & 0 & 1 & - & - & - & - \\
\hline Business Combinations & 25 & 2 & - & 37 & 0 & 25 & - & - & - & - \\
\hline Issuing equity securities & - & 1 & 2 & - & - & - & - & - & - & - \\
\hline Government grants & 0 & 0 & - & 0 & 0 & 2 & - & - & - & - \\
\hline Financing leases & - & - & - & 3 & - & - & - & - & - & - \\
\hline $\begin{array}{l}\text { Purchasing several fixed assets not } \\
\text { priced separately }\end{array}$ & - & - & - & 0 & - & - & - & - & - & - \\
\hline Cash & - & - & 70 & - & - & - & - & - & - & - \\
\hline Others & 2 & 1 & 5 & 0 & 0 & 1 & - & - & - & - \\
\hline \multicolumn{11}{|c|}{ Panel C: Whether used FV for initial measurement or not } \\
\hline Yes & 14 & 5 & 59 & 28 & 0 & 23 & 9 & 0 & 0 & 2 \\
\hline No & 12 & 4 & 19 & 14 & 0 & 7 & 29 & 0 & 0 & 4 \\
\hline
\end{tabular}




\begin{tabular}{|c|c|c|c|c|c|c|c|c|c|c|}
\hline Undisclosed & 3 & 2 & 1 & 0 & 0 & 4 & 61 & 0 & 0 & 15 \\
\hline \multicolumn{11}{|c|}{ Panel D: Implementation by the FV hierarchy } \\
\hline Level 1 & 0 & 0 & 0 & 0 & 0 & 0 & 1 & 0 & 0 & 0 \\
\hline Level 2 & 0 & 0 & 0 & 0 & 0 & 0 & 0 & 0 & 0 & 0 \\
\hline Level 3 & 8 & 5 & 49 & 24 & 0 & 23 & 6 & 0 & 0 & 0 \\
\hline Undisclosed & 6 & 0 & 10 & 4 & 0 & 4 & 2 & 0 & 0 & 2 \\
\hline
\end{tabular}


3.1.3 The implementation of conditionally mandatory FV requirements in initial measurement

The implementation of conditionally mandatory FV requirements in initial measurement only involves EAS 7 Exchange of Non-Monetary Assets. The standard stipulates that the FV of the assets and relevant payable taxes should be recognized as the cost of assets received when the exchange of non-monetary assets satisfies the following two conditions simultaneously: (1) the transaction has commercial substance; and (2) the FV of the assets received or surrendered can be measured reliably. In practice, only fourteen out of the 600 observations undertook the exchange of non-monetary assets, and only seven of them used FV while the others did not disclose relevant information. This suggests that few firms had exchanges of non-monetary assets and adopted FV measurement. The firms also had quite low quality of information disclosure.

\subsection{Implementation of FV requirements in subsequent measurement}

4.2.1 The implementation of mandatory FV requirements in subsequent measurement

Mandatory FV requirements for subsequent measurement are prescribed in EAS 10 Enterprise Annuity Fund and EAS 11 Share-Based Payment. Similar results with the findings reported in Table 3, fifty-six out of the 600 observations established enterprise annuity fund schemes but did not provide any detailed information on subsequent measurement. Unlike annuity fund, most firms with share-based payment well complied with the requirements of EAS 11 by using FV to recognize expenses on share-based payment.

4.2.2 The implementation of partially mandatory FV requirements in subsequent measurement

EAS 4 Fixed Asset, EAS 6 Intangible Assets, and EAS 27 Extraction of Petroleum and Natural Gas stipulate partially mandatory use of FV for subsequent measurement. The former two may involve FV measurement when firms have fixed assets or intangible assets held for sale. For example, EAS 4 specifies that fixed assets that are classified as held for sale are carried at the lower of the carrying amount and FV less relevant disposal costs. In practice, few firms had non-current assets held for sale. We find that only eight out of the 600 non-financial firm observations held fixed assets for sale while only one observation had intangible assets held for sale. Although seven out of the eight observations with fixed assets held for sale adopted FV measurement, only one employed asset appraiser to estimate the FV and two used the carrying amount less depreciation, while the others did not disclose relevant information. The one observation with intangible assets held for sale used the appraisal value as the FV. In addition, no sample firm involved EAS 27 Extraction of Petroleum and Natural Gas.

4.2.3 The implementation of conditionally mandatory FV requirements in subsequent measurement

EAS 5 Biological Assets requires enterprises to use FVA when meeting specific conditions. It prescribes that if there is conclusive evidence that the FV of a biological asset can be reliably obtainable on a continuing basis, the biological asset shall be measured at FV. Further, both of the following conditions shall be satisfied if FV is to be used for measurement purposes: (1) there is an active market for the biological assets; and, (2) the market price and other relevant information regarding the same or similar types of biological asset can be obtained from the market so that the FV 
of the biological asset can be reasonably estimated. We find that only seven out of the 600 non-financial firm-year observations held biological assets, involving two listed firms. However, the two firms did not adopt the FV model probably because it was difficult to satisfy the two conditions.

\subsubsection{The implementation of voluntary FV requirements in subsequent measurement}

EAS 3 Investment Property stipulates that firms should use the cost model in subsequent measurement, but can optionally use the FV model when there is an active property market and reliable market prices and other relevant information of identical or similar property can be continuously obtained. When the FV model is adopted, it also requires the disclosure of the basis and method used to determine the FV and the impact of FV changes on earnings. Our results show that 316 out of the 600 observations engaged in an investment property, involving seventy-three non-financial listed firms. However, only two firms (or eight observations) chose the FV model for subsequent measurement while the others used the cost model. Interestingly, this suggests that most listed firms were unwilling to adopt the FV model although they could optionally use it. More importantly, the two adopting firms disclosed inadequate information on how to determine the FV of an investment property.

\subsection{The use of FV in impairment}

The third type of FV adoption in EASs relates to the process of impairment testing. The adoption includes three forms, mandatory, conditionally mandatory, and partially mandatory.

First, the mandatory adoption of FVA in impairment tests involves the impairment of long-term equity investment (EAS 2), fixed assets (EAS 4), biological assets (EAS 5), intangible assets (EAS 6), and goodwill (EAS 8). For the impairment of long-term assets, one of the oldest accounting principles is that an asset must not be carried at more than the recoverable amount of the asset. FV plays an important role in estimating the recoverable amount because an entity can recover such assets by selling them. EAS 8 specifies that the recoverable amount of an asset is the higher of its FV less selling costs and the present value of the future cash flows expected to be derived from the asset.

Table 5 presents the statistics on the practical implementation of $\mathrm{FV}$ requirements for impairment tests. Panel A of Table 5 shows that sixty out of the 600 non-financial firm-year observations recognized impairment losses of long-term equity investments, involving forty listed firms. Most of them used a kind of appraisal value as the receivable amount to estimate the amount of impairment by comparing it with the carrying amount of long-term equity investment. However, these firms did not disclose information on how to identify the recoverable amount. In the notes to financial statements, they briefly stated that the recoverable amount of assets is the higher of FV less selling costs and the present value of the expected future cash flows, but did not disclose detailed information on the values and on how they were estimated. Instead, some firms disclosed the reasons for impairment of long-term equity investment, such as the investing entity's involvement in a lawsuit, bad performance, loss, or out of business.

With regard to fixed assets, Table 5 shows that 135 observations recognized impairment losses of fixed assets, involving sixty-three non-financial firms. Thirty-eight out of the 135 observations only disclosed the method of impairment testing, such as net realizable value or appraisal value, but did not 
provide any detailed information. Ninety-seven observations did not disclose relevant information. Two firms with biological assets did not recognize any impairment. We also find that, compared with fixed assets, firms were less likely to recognize any impairment losses of intangible assets given the greater difficulty in obtaining their $\mathrm{FV}$, and that the quality of disclosure on the impairment of intangible assets was lower as well. Table 6 shows that four percent of all twenty-four observations recognized impairment losses of intangible assets, involving fourteen listed firms. However, only six observations simply disclosed the method of impairment testing, such as the difference between recoverable value and carrying value, appraisal value, while the other eighteen observations did not disclose any information. Similar results can be found for the impairment of goodwill. Table 5 shows that seventeen out of the twenty-one observations recognizing the impairment losses of goodwill did not disclose relevant information on impairment testing, and only four disclosed the method of impairment.

Table 5 Implementation of FV requirements in impairment tests by non-financial firms

\begin{tabular}{|c|c|c|c|c|c|}
\hline & \multirow{2}{*}{$\begin{array}{l}\text { No. of observations } \\
\text { involving FV use in } \\
\text { impairment } \\
{[\% \text { of } 600 \text { observations }]}\end{array}$} & \multicolumn{4}{|c|}{ Use of FV by the FV hierarchy } \\
\hline & & Level 1 & Level 2 & Level 3 & Undisclosed \\
\hline \multicolumn{6}{|c|}{ Panel A: The implementation of mandatory $F V$ measurement for impairment tests } \\
\hline EAS 2 Long-Term Equity Investments & $60[10.00]$ & 0 & 0 & 48 & 12 \\
\hline EAS 4 Fixed Assets & $135[22.50]$ & 0 & 0 & 38 & 97 \\
\hline EAS 5 Biological Assets & $0[0]$ & 0 & 0 & 0 & 0 \\
\hline EAS 6 Intangible Assets & $24[4.00]$ & 0 & 0 & 6 & 18 \\
\hline EAS 8 Impairment of assets (Goodwill) & $21[3.50]$ & 0 & 0 & 4 & 17 \\
\hline \multicolumn{6}{|c|}{ Panel B: The implementation of conditionally mandatory $F V$ measurement for impairment tests } \\
\hline EAS 3 Investment Property & $9[0.15]$ & 0 & 0 & 0 & 9 \\
\hline \multicolumn{6}{|c|}{ Panel C: The implementation of partially mandatory FV measurement for impairment tests } \\
\hline EAS 27 Extraction of Petroleum and Nature Gas & $0[0]$ & 0 & 0 & 0 & 0 \\
\hline
\end{tabular}

Second, EAS 3 Investment Property requires firms to conduct impairment testing at the balance sheet data when using the cost model for the subsequent measurement of investment property. Although seventy-three sample firms chose the cost model, only five (involving nine observations) recognized an impairment loss of investment property. Further, we find that the impairment amount was largely due to the transfer from impaired fixed assets or inventories to investment property. The low probability for investment property impairment is largely related to the continuous rise of China's real estate prices in recent years.

Finally, EAS 27 Extraction of Petroleum and Natural Gas specifies that an entity shall recognize impairment losses on mineral interests in properties under one of the following two circumstances: (1) impairment of mineral interests in proved properties shall be accounted for in accordance with EAS 8; and (2) mineral interests in unproved properties shall be tested for impairment at least annually. An impairment loss on a mineral interest in an unproved property shall be recognized in profit or loss for the current period at the amount by which its FV is less than its carrying amount. This suggests that FVA is partially mandatory in the impairment of mineral interests in properties in China. Nevertheless, as the extractive transactions are largely concentrated on the industry of oil and gas, none of the 120 sample firms involved EAS 27.

Further, Table 6 presents statistics on the impact of FVA implementation in impairment testing during 2007 to 2011 on listed non-financial firms' reported net income, owners' equity and total assets. The raw data for the analysis are extracted from the CSMAR database. The impacts are calculated as total amount of impairment loss relating to fixed assets, long-term equity investment, intangible assets, 
investment property, and goodwill. The results show that mean (median) ratio of impairment losses over net income was 21.89 (4.58) percent, with the maximum ratio being 1773.86 percent, suggesting that the impairment loss had a large effect on reported earnings of Chinese listed firms, and the impacts were different across firms. On the balance sheets, the mean ratio of impairment losses over total assets (owners' equity) was 0.56 (1.13) percent, and the median ratio of impairment losses over total assets (owners' equity) was $0.14(0.30)$ percent, with the maximum ratio being 25.32 (48.46) percent. This indicates that the impact of impairment losses on the balance sheets is small, but is notable for some firms.

Table 6 Financial impact of impairment losses on the non-financial firms

\begin{tabular}{l|r|r|r|r|r|r}
\hline & \multicolumn{1}{|c|}{ Obs } & \multicolumn{1}{c|}{ Mean } & \multicolumn{1}{c|}{ Std. } & \multicolumn{1}{c|}{ Min } & \multicolumn{1}{c}{ Median } & \multicolumn{1}{c}{ Max } \\
\hline Impairment losses divided by net income & 404 & 21.89 & 99.53 & 0.00 & 4.58 & 1773.86 \\
\hline Impairment losses divided by total assets & 404 & 0.56 & 1.93 & 0.00 & 0.14 & 25.32 \\
\hline Impairment losses divided by owners' equity & 404 & 1.13 & 3.55 & -7.52 & 0.30 & 48.46 \\
\hline
\end{tabular}

4.4 Implementation of FV disclosure requirements in practice

Apart from voluntary disclosure, the disclosure of FV information can be mandatory, partially mandatory, and conditionally mandatory. EAS 8 Impairment of Assets, EAS 10 Enterprises Annuity Fund, EAS 11 Share-Based payment, EAS 12 Debt Restructurings, EAS 30 Presentation of Financial Statements, EAS 31 Cash Flow Statements, and EAS 38 First-Time Adoption of Accounting Standards for Business Enterprises, mandatorily require an entity to disclose FV information in the notes. For example, EAS 11 specifies that an enterprise should disclose the method of determining the FV of equity instruments in the notes. EAS 12 stipulates that a debtor (creditor) should disclose, in the notes, information on the methods and bases of determining the FV of (a) non-cash assets transferred (received), (b) capital converted from debt (equity interest received on conversion from debt receivable), and (c) the debt (receivable) after modification of other terms. FV information also is partially mandatorily required to be disclosed in the notes by EAS 4, EAS 20, EAS 21, and EAS 22. For instance, EAS 20 stipulates that for a business combination not involving enterprises under common control, the acquirer shall disclose, in the notes, information on the components of the cost of combination, their carrying amounts and FVs, and the methods of determining the FVs. Additionally, EAS 3 Investment Property and EAS 7 Exchange of Non-Monetary Assets require enterprises to mandatorily disclose FV information satisfying pre-conditions. For example, EAS 3 specifies that an enterprise shall disclose the information on the bases and methods applied in determining the FV and the effect of FV changes on profit or loss if the enterprise chooses the FV model for the subsequent measurement of investment property.

In general, while these standards require enterprises to disclose FV information on a mandatory, partially mandatory, or conditionally mandatory basis, our data analysis provided in parts 4.1, 4.2, and 4.3 indicates that the sample firms provide little disclosure on FV in the notes to financial statements during 2007 - 2011.

\subsection{Implementation of FV requirements relating to financial instruments}

In order to conform to special Chinese circumstances and well guide accounting practice, the 2006 EASs attempt to reduce the complexity transactions of financial instruments (thereafter FI) by dividing 
IFRS 39 Financial Instruments: Recognition and Measurement into three specific standards, that is, EAS 22 Recognition and Measurement of Financial Instruments, EAS 23 Transfer of Financial Assets, and EAS 24 Hedging. Meanwhile, EAS 37 Financial Instruments: Presentation and Disclosures further specifies the issues on information disclosure on FI. In these standards, FV is required for initial measurement and disclosure for all FI. Except for held-to-maturity investments and loans and receivables, firms are required to use FV for subsequent measurement of FI as well. In addition, enterprises also should use FV to test the impairment of financial assets except for trading financial assets. Apparently, FVA is largely applied to financial assets or liabilities in the 2006 EASs, representing a major de jure convergence with IFRS. However, how do Chinese non-financial listed firms implement these standards in practice?

Table 7 first presents industry distribution of non-financial firms with financial assets or liabilities. In this table, we represent manufacturing sub-industries by second-level industry codes, and other industries by the first-level industry codes. The results show that over half of the 600 non-financial firm-year observations (314 observations) held financial assets or liabilities. Particularly, the two highest ratios of observations with financial assets or liabilities divided by total industry observations are found in the industries of electronic manufacture (C5) and wholesale and retail trade (H). Meanwhile, firms from extraction (B) and farming, forestry, animal husbandry and fishery (A) held less financial assets or liabilities.

Table 7 Industry distribution of sample non-financial firms with financial assets or liabilities ${ }^{(3)}$

\begin{tabular}{lr}
\hline \multicolumn{1}{c}{ Categories } & $\begin{array}{r}\text { No. of obs. with financial assets or } \\
\text { liabilities [\% of industry obs.] }\end{array}$ \\
\hline Farming, forestry, animal husbandry and fishery (A) & $0[0]$ \\
Extraction (B) & $7[20.00]$ \\
Manufacture (C) & $118[45.56]$ \\
Including: Food and beverages (C0) & $16[35.56]$ \\
$\quad$ Textile, garment, leather, and feather (C1) & $11[73.33]$ \\
Petroleum, chemical, rubber, and plastics (C4) & $13[43.33]$ \\
Electronic (C5) & $14[93.33]$ \\
Metallic and nonmetal (C6) & $18[51.43]$ \\
Machinery, equipment, and instruments (C7) & $35[36.84]$ \\
Medicine and biological (C8) & $16[45.71]$ \\
Electric power, steam and hot water generation and supply (D) & $26[47.27]$ \\
Construction (E) & $2[40.00]$ \\
Transportation and warehousing (F) & $27[67.50]$ \\
Information technology (G) & $25[71.43]$ \\
Wholesale and retail trade (H) & $29[82.86]$ \\
Real estate (J) & $54[60.00]$ \\
Social services (K) & $5[50.00]$ \\
Media and culture services (L) & $5[100.0]$ \\
Conglomerates (M) & $11[73.33]$ \\
\hline Total & $314[52.3]$ \\
\hline
\end{tabular}

Table 8 reports the statistics on the implementation of FVA for financial assets or liabilities of sample non-financial firms. Trading financial assets include financial assets held for trading and those designated as at FV through profit or loss. The same classification is required for trading financial liabilities. As trading financial assets mainly consist of stocks, bonds, or funds that are purchased from

\footnotetext{
(3) Here financial assets or liabilities include trading financial assets or liabilities, available-for-sale financial assets, held-to-maturity investment, derivative financial assets or liabilities, financial assets purchased for resale, financial assets sold for repurchase, and hedging, but exclude loans and receivables because all sample firms held accounting receivables.
} 
secondary markets, the quoted prices of relevant assets or reliabilities are much easier to obtain from active markets. Table 8 shows that 163 out of the 600 observations held trading financial assets, involving fifty-four non-financial sample firms. Among these, 153 used the level $1 \mathrm{FV}$ measurement while ten did not disclose relevant information. Also, few firms held trading financial liabilities. The results also reveal that 202 observations held available-for-sale financial assets, involving fifty-four sample firms, and most used Level $1 \mathrm{FV}$ to recognize and measure the assets/liabilities. While FV is required to be used for initial and subsequent measurement of trading financial assets and available-for-sale financial assets, FV is only required for initial measurement of held-to-maturity investments. Table 8 shows that eleven non-financial firm-year observations (or ten firms) involved the mandatory requirements of using FV in the initial measurement of held-to-maturity, including ten firms. Among them, six used amortized cost instead of FV and the others did not disclose relevant information. Our data also show that all sample firms held loans and receivables. In addition, few sample firms held derivative financial assets or liabilities. In particular, nine sample firms held derivative financial assets, three held derivative financial liabilities, one held financial assets sold for repurchase, and four had hedging assets. Overall, Chinese listed non-financial firms mainly held trading financial assets and available-for-sale financial assets during 2007 to 2011, and they held few other financial assets or liabilities, particularly, derivative financial instruments. Most firms complied well with the 2006 EASs' requirements on the use of FV measurement and disclosed relevant information except for a few firms whose quality of information disclosure was low. Furthermore, Level $1 \mathrm{FV}$ was the main input for recognizing the FV of financial assets or liabilities.

Table 8 Implementation of FVA for financial assets or liabilities by non-financial firms

\begin{tabular}{|c|c|c|c|c|c|c|c|c|c|}
\hline & \multirow{2}{*}{$\begin{array}{l}\text { No. of Obs. } \\
\text { involving } \\
\text { mandatory FV } \\
\text { requirements } \\
\text { [\% of } 600 \mathrm{Obs} .]\end{array}$} & \multirow[t]{2}{*}{$\begin{array}{c}\text { Firms } \\
\text { involved }\end{array}$} & \multicolumn{3}{|c|}{$\begin{array}{l}\text { Whether used FV } \\
\text { measurement or not }\end{array}$} & \multicolumn{4}{|c|}{ Implementation by the FV hierarchy } \\
\hline & & & Yes & No & $\begin{array}{l}\text { Undis- } \\
\text { closed }\end{array}$ & $\begin{array}{c}\text { Level } \\
1\end{array}$ & $\begin{array}{c}\text { Level } \\
2\end{array}$ & $\begin{array}{c}\text { Level } \\
3\end{array}$ & $\begin{array}{l}\text { Undis- } \\
\text { closed }\end{array}$ \\
\hline Trading financial assets & $163[27.50]$ & 54 & 153 & 0 & 10 & 153 & & & 10 \\
\hline Trading financial liabilities & $27[4.50]$ & 11 & 22 & 0 & 5 & 17 & & 5 & 5 \\
\hline Available-for-sale financial assets & $202[33.67]$ & 54 & 189 & 2 & 11 & 184 & & 5 & 11 \\
\hline Held-to-maturity investments & $11[1.83]$ & 10 & 0 & 6 & 5 & & & & 5 \\
\hline Loans and receivables & $600[100.00]$ & 120 & 3 & 597 & 0 & 0 & 0 & 3 & 0 \\
\hline Derivative financial assets & $26[4.33]$ & 9 & 22 & & 4 & 18 & & 4 & 4 \\
\hline Derivative financial liabilities & $5[0.83]$ & 3 & 4 & & 11 & 2 & & 2 & 11 \\
\hline Financial assets purchased for resale & $0[00]$ & 0 & & & & & & & \\
\hline Financial assets sold for repurchase & $3[0.50]$ & 1 & & & & & & & \\
\hline Hedging & $10[1.67]$ & 4 & 9 & & 1 & 9 & & & 1 \\
\hline
\end{tabular}

Table 9 reports the impact of gains or losses from FV changes in FI and from investing FI on sample non-financial firms' financial statements. We derive the percentages by dividing the amount of gains (losses) from FV changes in FI or from investing FI by net income, total assets, and total owners' equity, respectively. Because a few firms had a negative net income, we dealt with them as absolute value. We also separately present the gains and losses as they have offsetting effects on earnings. Panel A of Table 9 shows that seventy-five out the 163 observations with gains or losses from FV changes in FI recognized gains, while eighty-eight recognized losses. On average, the gains from FV changes in FI accounted for 15.72 percent of net income, 0.29 percent of total assets, and 0.78 percent of total owners' equity, respectively. However, based on the medians, the percentages became 0.71 percent, 0.03 percent, and 0.07 percent, respectively. The mean (median) losses from FV changes in FI accounted for 14.18 
(0.80) percent of net income, $0.22(0.03)$ percent of total assets, and $0.57(0.10)$ percent of owners' equity, respectively. This suggests that, the effect of FV application to financial instruments on accounting earnings was relatively small. However, the effect should be notable for a few firms because the gains and losses from FV changes in FI were quite volatile across the sample firms.

Similar results can be found for gains from investment in FI. Panel B of Table 9 shows that among the 213 non-financial firm-year observations that recognized investment gains or losses in the sample period, more firms (accounting for 195 observations) recognized investment gains in FI, while few firms suffered investment losses. The mean (median) ratio of gains from investment in FI over net income was 23.94 (1.83) percent, with the standard deviation being 85.02. This indicates that the impact of gains from investing in FI on the income statements was significant, but was volatile across the sample firms. The mean ratio of gains from investment in FI was 0.63 percent of total assets and 1.25 percent of owners' equity, respectively, with the median percentages being 0.07 percent and 0.18 percent respectively. This suggests that the impact of gains from investing in FI on the balance sheet was small. In addition, few firms (only 18 observations) recognized losses from investment in FI and the losses had less effect on financial performance than did gains.

Table 9 The impact of the application of FVA to FI in the financial performance of non-financial firms

\begin{tabular}{|c|c|c|c|c|c|c|}
\hline & Obs & Mean & Std. & Min & median & $\operatorname{Max}$ \\
\hline \multicolumn{7}{|l|}{ Panel A:Gains or losses from FV changes in FI } \\
\hline Gains from FV changes in FI divided by net income & 75 & 15.72 & 84.49 & 0.00 & 0.71 & 729.8 \\
\hline Gains from FV changes in FI divided by total assets & 75 & 0.29 & 0.50 & 0.00 & 0.03 & 2.11 \\
\hline Gains from FV changes in FI divided by owners' equity & 75 & 0.78 & 1.43 & 0.00 & 0.07 & 6.86 \\
\hline Losses from FV changes in FI divided by net income & 88 & 14.18 & 62.64 & 0.00 & 0.80 & 521.97 \\
\hline Losses from FV changes in FI divided by total assets & 88 & 0.22 & 0.45 & 0.00 & 0.03 & 3.17 \\
\hline $\begin{array}{l}\text { Losses from FV changes in FI divided by owners' } \\
\text { equity }\end{array}$ & 88 & 0.57 & 1.32 & 0.00 & 0.10 & 10.37 \\
\hline \multicolumn{7}{|l|}{ Panel B: Gains or losses from investing in FI } \\
\hline Gains from investing in FI divided by net income & 195 & 23.94 & 85.02 & 0.00 & 1.83 & 740.42 \\
\hline Gains from investing in FI divided by total assets & 195 & 0.63 & 1.67 & 0.00 & 0.07 & 14.99 \\
\hline Gains from investing in FI divided by owners' equity & 195 & 1.25 & 3.19 & 0.00 & 0.18 & 30.74 \\
\hline Losses from investing in FI divided by net income & 18 & 4.56 & 14.96 & 0.00 & 0.16 & 63.89 \\
\hline Losses from investing in FI divided by total assets & 18 & 0.07 & 0.21 & 0.00 & 0.00 & 0.89 \\
\hline Losses from investing in FI divided by owners' equity & 18 & 0.20 & 0.55 & 0.00 & 0.01 & 2.37 \\
\hline
\end{tabular}

\section{Implementation of FVA by listed Chinese financial firms}

This section will first show the extent of application of FVA to FI by listed Chinese financial firms during 2007-2011. We will then provide evidence on the financial effect of FVA application to FI on financial firms. The implementation of FVA for non-financial instruments for listed Chinese financial firms will be presented in this section as well.

5.1 Implementation of FVA for financial instruments

Consistent with non-financial firms, Chinese financial firms are also mandatorily required by the 2006 EASs to use FV for initial measurement of FI and to disclose related FV information.

Table 10 summarizes the implementation of FVA for FI in listed Chinese financial firms during 2007-2011. As financial firms often simultaneously held several financial products such as stock, bond or fund, in an accounting period, and might use different levels of input in the FV hierarchy for financial assets or liabilities. Generally, financial firms held more financial assets and liabilities than 
non-financial firms. Table 10 shows that all twenty-seven sample financial firms (or 131 observations) held trading financial assets, and used FV as the measurement basis. The results also show that 120 observations with trading financial assets used Level $1 \mathrm{FV}$ while 123 used Level $3 \mathrm{FV}$. This suggests that the quoted prices from active markets and appraisal values using valuation technologies were the two main inputs for measuring the FV of trading financial assets. Fifty-seven out of the 135 observations representing fifteen financial firms held trading financial liabilities. Among them, forty-three (forty-seven) observations used Level $1 \mathrm{FV}$ (Level $3 \mathrm{FV}$ ) while fourteen used Level $2 \mathrm{FV}$.

Table 10 also shows that twenty-six out of twenty-seven sample firms accounting for 127 observations held available-for-sale financial assets. Similar to trading financial assets, the quoted prices from active markets (Level $1 \mathrm{FV}$ ) and appraisal values (Level $3 \mathrm{FV}$ ) were the main inputs for identifying the FV of available-for-sale financial assets. Only thirty-nine observations with available-for-sale financial assets used Level $2 \mathrm{FV}$. The data also indicates that Chinese financial firms had relatively high quality of FV information disclosure on available-for-sale financial assets, and trading financial assets and liabilities. Nevertheless, these findings were not applicable to held-to-maturity investment. The results show that sixty-eight out of the 135 observations engaged in the initial measurement of held-to-maturity investments, involving nineteen financial firms. Further, bond investment was a dominant form of held-to-maturity investments. However, these firms only disclosed the objects of held-to-maturity investment, such as national bonds, local government bonds, corporate bonds, short-term financing bonds, etc., but did not disclose any information on how to initially measure and recognize them using FV. We find that twenty-one observations only disclosed that the measurement basis for held-to-maturity investments was FV, without other information. Forty-seven observations did not disclose any information. Additionally, Table 10 shows that while all sample financial firms held loans and receivables, they did not use FV as the measurement basis. Few firms stated in the notes that the initial measurement of the amount of loans and receivables was based on the $\mathrm{FV}$ at the date of acquirement.

Table 10 Implementation of FVA for FI by listed financial firms

\begin{tabular}{|c|c|c|c|c|c|c|c|c|c|}
\hline & \multirow{2}{*}{$\begin{array}{l}\text { No. of Obs. } \\
\text { involving } \\
\text { mandatory FV } \\
\text { requirements } \\
\text { [\% of } 135 \text { Obs.] }\end{array}$} & \multirow[t]{2}{*}{$\begin{array}{c}\text { Firms } \\
\text { involved }\end{array}$} & \multicolumn{3}{|c|}{$\begin{array}{l}\text { Whether used FV } \\
\text { measurement or not }\end{array}$} & \multicolumn{4}{|c|}{ Implementation by the FV hierarchy } \\
\hline & & & Yes & No & $\begin{array}{l}\text { Undis- } \\
\text { closed }\end{array}$ & $\begin{array}{c}\text { Level } \\
1\end{array}$ & $\begin{array}{l}\text { Level } \\
2\end{array}$ & $\begin{array}{l}\text { Level } \\
3\end{array}$ & $\begin{array}{l}\text { Undis- } \\
\text { closed }\end{array}$ \\
\hline Trading financial assets & $131[97.04]$ & 27 & 131 & 0 & 0 & 120 & 42 & 123 & 0 \\
\hline Trading financial liabilities & $57[42.22]$ & 15 & 57 & 0 & 0 & 43 & 14 & 47 & 0 \\
\hline Available-for-sale financial assets & $127[94.07]$ & 26 & 127 & 0 & 0 & 115 & 39 & 115 & 0 \\
\hline Held-to-maturity investments & $68[50.37]$ & 19 & 21 & 0 & 47 & 0 & 0 & 0 & 21 \\
\hline Loans and receivables & $135[100]$ & 27 & 0 & 135 & 0 & 0 & 0 & 0 & 0 \\
\hline Derivative financial assets & $89[65.93]$ & 22 & 89 & 0 & 0 & 54 & 26 & 73 & 0 \\
\hline Derivative financial liabilities & $83[61.48]$ & 19 & 83 & 0 & 0 & 52 & 26 & 73 & 0 \\
\hline Financial assets purchased for resale & $108[80]$ & 25 & - & - & - & - & - & - & - \\
\hline Financial assets sold for repurchase & $114[84.44]$ & 25 & - & - & - & - & - & - & - \\
\hline Hedging & $5[3.70]$ & 3 & 4 & 0 & 1 & 4 & 0 & 0 & 1 \\
\hline
\end{tabular}

Unlike non-financial firms, we find that financial firms held many derivative financial products. Table 10 shows that twenty-two sample financial firms (or eighty-nine observations) held derivative financial assets and used FV as the measurement basis. Nineteen sample financial firms (amounting to eighty-three observations) held derivative financial liabilities and used FV measurement. Furthermore, fifty-four observations with derivative financial assets used Level $1 \mathrm{FV}$, twenty-six used Level $2 \mathrm{FV}$, and seventy-three used Level $3 \mathrm{FV}$. Similar results were obtained for derivative financial liabilities. 
This suggests that the quoted prices from active markets and appraisal values were again the two main inputs for FV measurement of derivative financial assets and liabilities. Many financial firms also held financial assets purchased for resale and financial assets sold for repurchase, with 108 observations and 114 observations, respectively. In addition, few financial firms held assets for hedging.

Further, we summarize the impact of gains (losses) from FV changes in FI and from investing in FI on the sample financial firms' financial statements. Consistently, the amounts of gains (losses) from FV changes in FI and from investment in FI are scaled by net income, total assets, and owners' equity, respectively. The results reported in Table 11 show that forty-seven observations recognized gains from FV changes in FI while fifty-eight recognized losses. The mean (median) ratio of gains from FV changes in FI over net income is 5.49 (2.23) percent, suggesting that the implementation of FVA for FI resulted in considerable effect on financial firms' earnings. The biggest impact was as much as 33.06 percent of net income. The gains from FV changes in FI also on average accounted for 0.31 percent of total assets, and 1.32 percent of owners' equity. Nevertheless, FV changes in FI caused the sample financial firms to suffer more losses. Panel A of Table 11 indicates that the losses from FV changes in FI on average accounted for 32.66 percent of net income, 0.68 percent of total assets, and 2.40 percent of owners' equity, respectively. Meanwhile, the 142.5 percent of standard deviation indicates that the impact of relevant losses on accounting earnings varied significantly across financial firms.

Panel B in Table 11 reports the impact of gains or losses from investing in FI on financial firms' financial statements. In general, more firms (105 observations) recognized gains from investing in FI. Panel B shows that the mean (median) ratio of gains from investing in FI over net income was 52.13 (23.87) percent, indicating the gains related to investment in FI increase by nearly a quarter of accounting earnings for financial firms. On average, gains from investing in FI accounted for 1.56 percent of total assets and 6.88 percent of owners' equity. In contrast, losses from investing in FI had a small influence on financial statements of the sample financial firms.

Table 11 The financial impact of FVA for FI on financial firms

\begin{tabular}{|c|c|c|c|c|c|c|}
\hline & Obs & Mean & Std. & Min & median & $\operatorname{Max}$ \\
\hline \multicolumn{7}{|l|}{ Panel A:Gains or losses from FV changes in FI } \\
\hline Gains from FV changes in FI divided by net income & 47 & 5.49 & 7.27 & 0.07 & 2.23 & 33.06 \\
\hline Gains from FV changes in FI divided by total assets & 47 & 0.31 & 0.70 & 0.00 & 0.03 & 4.01 \\
\hline Gains from FV changes in FI divided by owners' equity & 47 & 1.32 & 2.55 & 0.01 & 0.30 & 14.80 \\
\hline Losses from FV changes in FI divided by net income & 58 & 32.66 & 142.5 & 0.08 & 4.65 & 1080.61 \\
\hline Losses from FV changes in FI divided by total assets & 58 & 0.68 & 1.77 & 0.00 & 0.07 & 10.88 \\
\hline $\begin{array}{l}\text { Losses from FV changes in FI divided by owners' } \\
\text { equity }\end{array}$ & 58 & 2.40 & 5.50 & 0.01 & 0.44 & 27.54 \\
\hline \multicolumn{7}{|l|}{ Panel B: Gains or losses from investing in FI } \\
\hline Gains from investing in FI divided by net income & 105 & 52.13 & 119.9 & 0.00 & 23.87 & 1058.10 \\
\hline Gains from investing in FI divided by total assets & 105 & 1.56 & 2.45 & 0.00 & 0.45 & 11.33 \\
\hline Gains from investing in FI divided by owners' equity & 105 & 6.88 & 11.04 & 0.00 & 1.93 & 54.38 \\
\hline Losses from investing in FI divided by net income & 25 & 0.63 & 2.33 & 0.00 & 0.01 & 11.43 \\
\hline Losses from investing in FI divided by total assets & 25 & 1.90 & 6.00 & 0.00 & 0.19 & 28.93 \\
\hline Losses from investing in FI divided by owners' equity & 25 & 8.86 & 20.03 & 0.00 & 1.22 & 74.40 \\
\hline
\end{tabular}

5.2 Implementation of FVA for non-financial instruments

5.2.1 of financial firms' use of FV for initial measurement of non-financial instruments

Table 12 summarizes the implementation of mandatory FV requirements for initial measurement 
in financial firms. The results show that sixty-six out of the 135 observations (or 48.89 percent) involved EAS 10 Enterprises Annuity Fund. However, the firms only mentioned that they established annuity fund schemes for employees but did not disclose detailed information on FV. This is consistent with the findings on listed non-financial firms, suggesting that Chinese listed firms had very low quality of disclosures. Table 12 also shows that thirty-two out of the 135 observations involved EAS 11 and most of them used the appraisal value (Level $3 \mathrm{FV}$ ) as the input of FVs of stock options or restricted stocks.

Table 12 Implementation of mandatory FV requirements for initial measurement by financial firms

\begin{tabular}{|c|c|c|c|}
\hline & & $\begin{array}{c}\text { EAS } 10 \text { Enterprises } \\
\text { Annuity Fund }\end{array}$ & $\begin{array}{c}\text { EAS } 11 \text { Share-Based } \\
\text { Payment }\end{array}$ \\
\hline $\begin{array}{l}\text { No. of observations ir } \\
\text { for initial measureme } \\
{[\% \text { of } 132 \text { observation }}\end{array}$ & lving mandatory FV requirements & $\begin{array}{r}66 \\
{[48.89]}\end{array}$ & $\begin{array}{r}32 \\
{[23.70]} \\
\end{array}$ \\
\hline $\begin{array}{l}\text { Whether use FVA in } \\
\text { initial measurement }\end{array}$ & $\begin{array}{l}\text { Yes } \\
\text { No } \\
\text { Undisclosed }\end{array}$ & $\begin{array}{r}- \\
- \\
66\end{array}$ & $\begin{array}{r}32 \\
0 \\
0 \\
\end{array}$ \\
\hline $\begin{array}{c}\text { Implementation of } \\
\text { FVA by levels of the } \\
\text { FV hierarchy }\end{array}$ & $\begin{array}{l}\text { Level } 1 \\
\text { Level } 2 \\
\text { Level } 3 \\
\text { Undisclosed }\end{array}$ & $\begin{array}{r}- \\
- \\
- \\
66\end{array}$ & $\begin{array}{r}2 \\
0 \\
25 \\
5\end{array}$ \\
\hline
\end{tabular}

Table 13 reports the statistics on implementation of partially mandatory FV requirements for initial measurement in financial firms. We find that the sample financial firms did not involve in FVA measurement in inventories, biological assets, revenues, government grants, and leases. In contrast, the implementation of partially mandatory FV requirements for initial measurement was more related to EAS 20 Business Combinations. The results show that twenty out of the 135 observations engaged in business combinations not under common control, and nearly three quarters used FV for initial measurement of related assets or liabilities. A quarter indicated in the notes that the reason for using the carrying value instead of FV was that there was no significant difference between the carrying amounts of identifiable assets and liabilities and their FVs at the acquired data. Although fourteen observations used FV, over half of them (eight observations) did not disclose information on how to identify the FVs of related assets and liabilities. The twenty observations relating to business combinations not under common control were closely related to the implementation of FV requirements for initial measurement of fixed assets and intangible assets. Table 13 shows that all eighteen observations involving the partially mandatory FV requirements for initial measurement of fixed assets were due to business combinations not under common control, but only twelve measured FV of related fixed assets, while six used carrying value. Ten out of the eleven observations involving the partially mandatory FV requirements for initial measurement of intangible assets was because of business combinations not under common control. Among them, nine used FVs of intangible assets while two used carrying values. Moreover, few financial firms engaged in debt restructurings; if any firm did, its quality of relevant information disclosure was low.

Finally, our data shows that only one out of the 600 observations had exchanges of non-monetary assets. However, the firm involved argued in the notes that the exchange transaction had no commercial substance and thus did not use FV measurement. 
Table 13 Implementation of partially mandatory FV requirements for initial measurement by financial firms

\begin{tabular}{|c|c|c|c|c|c|}
\hline & $\begin{array}{c}\text { EAS } 2 \\
\text { Long-term } \\
\text { Equity } \\
\text { Investments } \\
\end{array}$ & $\begin{array}{c}\text { EAS } 20 \\
\text { Business } \\
\text { Combinations }\end{array}$ & $\begin{array}{l}\text { EAS } 4 \\
\text { Fixed } \\
\text { Assets }\end{array}$ & $\begin{array}{c}\text { EAS } 6 \\
\text { Intangible } \\
\text { Assets }\end{array}$ & $\begin{array}{l}\text { EAS } 12 \\
\text { Debt } \\
\text { Restruct- } \\
\text { urings }\end{array}$ \\
\hline \multicolumn{6}{|l|}{ Panel A: Whether used the standard } \\
\hline $\begin{array}{l}\text { No. of observations involving partially } \\
\text { mandatory FV requirements for initial } \\
\text { measurement } \\
\text { [\% of } 135 \text { observations] }\end{array}$ & [1.48] & [14.93] & [3.33] & [8.15] & [5.19] \\
\hline \multicolumn{6}{|l|}{ Panel B: The way the asset acquired } \\
\hline Exchange of non-monetary assets & & & & 1 & \\
\hline Debt restructurings & 2 & & & & \\
\hline Business combinations & & & 18 & 10 & \\
\hline \multicolumn{6}{|c|}{ Panel C: Whether used FV in initial measurement } \\
\hline Yes & 2 & 14 & 12 & 9 & 2 \\
\hline No & 0 & 6 & 6 & 2 & 0 \\
\hline Undisclosed & 2 & 0 & 0 & 0 & 5 \\
\hline \multicolumn{6}{|l|}{ Panel D: Implementation by the FV hierarchy } \\
\hline Level 1 & 0 & 1 & 0 & 0 & 1 \\
\hline Level 2 & 0 & 0 & 0 & 0 & 0 \\
\hline Level 3 & 0 & 5 & 4 & 5 & 1 \\
\hline Undisclosed & 2 & 8 & 8 & 4 & 0 \\
\hline
\end{tabular}

5.2.2 Implementation of FVA in subsequent measurement of non-financial instruments by financial firms

First, regarding the implementation of mandatory FV requirements for subsequent measurement of non-financial instruments, Table 12 shows that although some firms established annuity fund schemes and recognized the annuity fund, they did not provide relevant information in the notes. Twenty-seven observations (six financial firms) disclosed the methods for estimating FV of equity instruments. Among them, five firms used valuation models such as Black-Scholes' option pricing model to estimate the FV of equity instruments while one firm directly used the quoted prices from active markets. Furthermore, two firms disclosed detailed information on the assumptions, parameters, and inputs for valuation models.

Second, no sample financial firms involved in the implementation of partially and conditionally mandatory FV requirements for subsequent measurement during 2007 to 2011.

Finally, the sample financial firms were more likely to engage in investment property and to choose the FV model for subsequent measurement of investment property than non-financial firms. Our data shows that seventeen of the twenty-seven financial firms (accounting for seventy-seven observations) held investment property during 2007 to 2011. Among them, twelve firms used the cost model while five firms used the FV model as subsequent measurement basis. We also find that one firm used Level $2 \mathrm{FV}$ while the other four firms used the appraisal value as the FV of investment property. The firms also disclosed relatively adequate information on how to identify the FV of investment property.

Further, we summarize the effect of the de facto use of FV for measuring investment property on financial firms' financial statements. The unreported results show that the mean (median) ratio of 
investment property over total assets was 0.62 (0.07) percent, with the maximum ratio being 12.35 percent, suggesting that the amount of investment property was considerably small compared with the total assets of financial firms. The mean (median) ratio of gains from FV changes in investment property over net income was $0.72(0.22)$ percent, ranging from -6.66 percent to 9.65 percent. This indicates that the effect of FVA for investment property on accounting earnings of financial firms was relatively small.

\section{Implementation of FVA in impairment of assets}

Table 14 reports that the statistics on impairment losses of relevant assets recognized by financial firms. In the process of impairment tests, FV was largely used to determine the recoverable amount of assets, and then to calculate the amount of impairment losses. In total, the sample financial firms were less likely to recognize impairment losses of assets, and predominately used the appraisal value as Level $3 \mathrm{FV}$ to estimate the amount of losses. For example, the results reported in Table 14 show that seventeen and nineteen observations, accounting for 12.59 percent and 14.07 percent of 135 financial firm observations, recognized the impairment losses of long-term equity investment and fixed assets, respectively. Fewer sample firms recognized the impairment loss of intangible assets due to the greater difficulty in estimating their FVs. One out of the fifty-four observations with investment property measured the assets using the cost model and recognized an impairment loss but the amount of loss was insignificant. Notably, over a quarter of observations recognized impairment losses of available-for-sale financial assets. These firms were more likely to use quoted prices from active markets (Level $1 \mathrm{FV}$ ) or appraisal values derived by using valuation technologies (Level $3 \mathrm{FV}$ ) to identify the FV of available-for-sale financial assets at the balance sheet date. Additionally, fourteen observations recognized impairment losses of held-to-maturity investments, accounting for 10.37 percent of the 135 observations, and all used Level $3 \mathrm{FV}$. The high probability of recognizing impairment losses of financial assets was related to more financial assets held by financial firms.

Table 14 Implementation of FVA for impairment tests by financial firms

\begin{tabular}{|c|c|c|c|c|c|}
\hline & \multirow{2}{*}{$\begin{array}{c}\text { No. of observations } \\
\text { incurred impairment } \\
\text { [\% of } 135 \text { observations }]\end{array}$} & \multicolumn{4}{|c|}{ Implementation by the FV hierarchy } \\
\hline & & $\begin{array}{l}\text { Level } 1 \\
\text { FV }\end{array}$ & $\begin{array}{l}\text { Level } 2 \\
\text { FV }\end{array}$ & $\begin{array}{l}\text { Level } 3 \\
\text { FV }\end{array}$ & $\begin{array}{l}\text { Undis- } \\
\text { closed }\end{array}$ \\
\hline Impairment of long-term equity investments & $17[12.59]$ & 0 & 9 & 8 & 0 \\
\hline Impairment of fixed assets & $19[14.07]$ & 0 & 0 & 19 & 0 \\
\hline Impairment of intangible assets & $4[2.96]$ & 0 & 0 & 4 & 0 \\
\hline Impairment of investment property & $1[0.74]$ & 0 & 0 & 0 & 1 \\
\hline $\begin{array}{l}\text { Impairment of available-for-sale financial } \\
\text { assets }\end{array}$ & $35[25.94]$ & 29 & 6 & 34 & 0 \\
\hline Impairment of held-to-maturity investments & $14[10.37]$ & 0 & 0 & 14 & 0 \\
\hline
\end{tabular}

Further, Table 15 summarizes the effect of FVA for impairment of assets on financial firms' financial statements. Similarly, we divided impairment losses involved in Table 14 by net income, total assets, and owners' equity, respectively. Overall, the effect of FVA for impairment of assets on income statements and balance sheets was small except for a few firms. In particular, the results show that the mean (median) ratio of impairment loss over net income was 37.89 (0.89) percent, ranging from -0.80 percent to 1588.62 percent. On average, the amount of impairment loss accounted for 0.22 percent of total assets and 1.55 percent of owners' equity, respectively.

Table 15 The financial effect of FVA for asset impairment on financial firms 


\begin{tabular}{l|r|r|r|r|r|r}
\hline & \multicolumn{1}{|c|}{ Obs } & \multicolumn{1}{c|}{ Mean } & \multicolumn{1}{c|}{ Std. } & \multicolumn{1}{c|}{ Min } & \multicolumn{1}{c}{ Median } & \multicolumn{1}{c}{ Max } \\
\hline Impairment loss divided by net income & 55 & 37.89 & 214.82 & -0.80 & 0.89 & 1588.62 \\
\hline Impairment loss divided by total assets & 55 & 0.22 & 0.57 & -0.00 & 0.01 & 3.69 \\
\hline Impairment loss divided by owners' equity & 55 & 1.55 & 5.44 & -0.14 & 0.15 & 38.68 \\
\hline
\end{tabular}

\section{Conclusions}

This study investigates the extent of adoption of FVA in the 2006 EASs and the implementation in practice by listed financial and non-financial firms. On February 5, 2006, the MoF released one revised conceptual framework and thirty-eight specific standards, which are largely based on IFRSs, with effect for China's listed firms from January 1, 2007. As one of the most important changes and a key feature, FVA which was previously abandoned in the Enterprises Accounting System stipulated by the MoF in 2000, was required or permitted for initial measurement, subsequent measurement and impairment recognition, and disclosures. We find that more than twenty-three standards of the thirty-eight EASs require or permit FVA, with four different forms of requirements ranging from mandatory, partially mandatory, conditionally mandatory, to voluntary.

Further, this study empirically investigates the de facto implementation of FVA by China's listed firms by using the annual reports of 120 firms randomly drawn from all China's listed firms, and all twenty-seven non-financial firms for the period of 2007 to 2011. Both sample financial and non-financial firms complied well with the mandatory or partially mandatory requirements concerning the use of FV to measure assets, liabilities, or transactions, but the quality of their FV information disclosure in the notes to financial statements was very low. Meanwhile, although mandatorily required, our sample firms were less likely to recognize impairment losses on goodwill and intangible assets than on fixed assets probably because it was more difficult to obtain and measure their FV. When firms were required to conditionally use FV to measure such assets, liabilities, or transactions (ALTs) as those involved in exchange of non-monetary assets, few firms had such ALTs; if they had, they did not prefer FV measurement. Although firms were also allowed to optionally use the FV model for subsequent measurement of investment property when reliable market prices and other relevant information of identical or similar assets can be continuously obtained, few sample firms (especially non-financial firms) preferred the FV model. And if they did use the FV model, the quality of the adopters' information disclosure was also low.

The sample firms tended to use external asset appraisers to estimate the FV of non-financial assets or liabilities. Some even directly used the carrying value as the FV of relevant assets or liabilities. In contrast, most firms determined the FV of financial assets or liabilities by using quoted prices of identical assets or liabilities in the active markets or appraisal values from asset appraisers. The firms also disclosed more FV information related to financial assets or liabilities. Finally, we find that the impact of FVA implementation in FI on financial statements was more significant for sample financial firms than that for sample non-financial firms during 2007 to 2011.

Overall, these findings indicate that FVA was widely adopted not only in EASs, but also in practice in our sample period. However, the level of implementation of FVA by listed firms was lower for non-financial assets or liabilities, but was relatively higher for financial assets or liabilities. This is consistent with the FVA implementation problems identified by the several practitioner speakers at the ICAEW's 2011 Information for Better Markets Conference, e.g., Harrington (2011), Harris (2011), and 
Wallace (2011).

Several Chinese institutional characteristics may have had a negative effect on the implementation of FVA. First, influenced by the former Soviet Union, China has a strong tradition of adopting uniform accounting systems (UAS) (Xiao et al., 2004; Ezzamel et al., 2007; Ezzmel and Xiao, 2015). This UAS tradition stresses uniform statutory control, rather than professional judgment which is required for effective implementation of FVA. Second, while improving rapidly, the Chinese accounting infrastructure is not well-developed due to the suspension of higher education during the Cultural Revolution and of the accounting profession between the 1950s and the 1980s (Xiao et al., 2000). This means that accountants, auditors, regulators and users are not equipped with sufficient FVA knowledge and experience and the needed professionalism, and thus may affect the level of implementation of FVA in practice. Third, it is well-recognized that the implementation of FVA requires well-developed asset pricing markets (such as the capital market and property market) (Zeff, 2007). This is because the more developed the markets, the easier to obtain Level $1 \mathrm{FV}$ which is more reliable and relevant than Levels 2 and 3 FVs (Song et al., 2009). Although improving, the market conditions for applying FVA are less conducive in China and it is difficult to obtain FV for many assets (Xiao et al., 2004; MoF, 2008, 2009 and 2010). Fourth, the weaker corporate governance mechanisms and legal enforcement in China also may have a negative effect on the implementation of FVA.

Overall, we believe that the results have several important policy implications for standards setters and the regulators of listed firms. First, there is a need to perfect FV accounting standards and provide more typical cases and greater operational guidance on the application of FVA. Because of the influence by the former Soviet Union, China has a strong uniform accounting system (UAS) tradition which stresses uniformity and statutory control. This is less conducive to the FVA implementation as the high complexity of estimating the FV (in particular at Level 3) of relevant assets or liabilities, the high need for significantly more professional judgment, and the lack of FV-related technical knowledge. This is one of the reasons for the low level of FVA implementation. Second, it is very important to improve the quality of FV information disclosure, given the extremely low amount and quality of FV information disclosed in the notes to financial statements. Third, the need for separate standards for financial and non-financial firms, particularly for financial instruments standards, should be taken into serious consideration. We find that financial firms held significant more complex financial instruments than non-financial firms; importantly, the adoption of FVA for financial instruments had a significantly greater effect on financial statements of financial firms. Using the same accounting standards may reduce the quality of FVA implementation. Finally, there is a need to improve relevant regulatory measures relating to firms, asset appraisers, and external auditors. The results show that listed firms largely rely on the work of external asset appraisers because of the high complexity of FVA and the lack of FV-related knowledge. Therefore, the external asset appraisers' and independent auditors' professionalism and independence are crucial to maintain the high quality of FV information.

\section{References}

Albu, N. and Albu, C. (2012) 'International Financial Reporting Standards in an emerging economy: Lessons from Romania’, Australian Accounting Review, 22: 341-352. 
Boolaky, P. K. (2010) 'IFRS in small Island economies: Problems and challenges to the private and public-sector enterprises: Using data from Mauritius', unpublished thesis.

Dai, B., Lu, Z. and Zhang, R. (2007) 'Write-downs: Conservatism or earnings management', Accounting Research (in Chinese), 12: 36-42.

Deloitte Touche Tohmatsu. (2006) 'China’s new accounting standards', unpublished thesis.

Ebrahim, A. and Fattah, T.A. (2015) 'Corporate governance and initial compliance with IFRS in emerging markets: The case of income tax accounting in Egypt', Journal of International Accounting, Auditing and Taxation, 24: 46-60.

Ezzamel, M. and Xiao, Z. (2015). 'The development of accounting regulations for foreign invested firms in China: The role of Chinese characteristics', Accounting, Organizations and Society, 44(4): 60-84.

Ezzamel, M., Xiao, Z., and Pan, A. (2007). 'Political Ideology and Accounting Regulation in China', Accounting, Organizations and Society, 32 (7/8): 669-700.

Feng, S. (2001). Overview of Enterprise Accounting System Lectures, In Department of Accounting, MoF (eds), Enterprise Accounting System Lectures, Beijing: China Finance and Economic Press.

Feng, S. (2003) 'The internationalization of accounting under current circumstance in China', Accounting Research (in Chinese), 2: 1-6.

Harris, T. 'Financial instruments in insurance companies', paper presented at the ICAEW 2011 Information for Better Markets Conference on Accounting for Financial Instruments: Everybody's Problem?, London, December 2011.

Harrington, R. 'Financial instruments in non-financial firms', paper presented at the ICAEW 2011 Information for Better Markets Conference on Accounting for Financial Instruments: Everybody's Problem?, London, December 2011.

He, X., Wong, T.J. and Young, D. (2012) 'Challenges for implementation of fair value accounting in emerging markets: Evidence from China', Contemporary Accounting Research, 29: 538-562.

Laux, C. and Leuz, C. (2009), The crisis of fair-value accounting: Making sense of the recent debate', Accounting, Organizations and Society, 34: 826-834.

Lijing. and Li, B. (2010) 'The value-relevance of fair value measures for commercial banks: Evidences from the Chinese bank industries', International Research Journal of Finance and Economics, 60: 86-93.

Ministry of Finance, China. (2008) 'A report of an analysis accounting standards implementation by listed Chinese firms in 2007', Http://www.EASC.gov.cn.

Ministry of Finance, China. (2009) 'A report of an analysis accounting standards implementation by listed Chinese firms in 2008', Http://www.EASC.gov.cn.

Ministry of Finance, China. (2010) 'A report of an analysis accounting standards implementation by listed Chinese firms in 2009', Http://www.EASC.gov.cn.

Peng, S. and Bewley, K. (2009) 'Adaptability of fair value accounting in China: Assessment of an emerging economy converging with IFRS', unpublished thesis, York University.

Peng, S. and Bewley. K. (2010) 'Adaptability to fair value accounting in an emerging economy: A case study of China's IFRS convergence', Accounting, Auditing \& Accountability Journal, 23: 
982-1011

Peng, S., Graham, C. and Bewley, K. (2013) 'Fair value accounting reforms in China: Towards an accounting movement theory', unpublished thesis, York University.

Qu, X. and Zhang, G. (2015) 'Value-relevance of earnings and book value over the institutional transition in China: The suitability of fair value accounting in this emerging market', The International Journal of Accounting, 50: 195-223.

Samaha, K. and Khlif, H. (2016) 'Compliance with IAS/IFRS and its determinants: A meta-analysis', Journal of Accounting-Business \& Management, 23: 41-63.

Song, C.J., Thomas, W. and Yi, H. (2010) 'Value relevance of FAS 157 fair value hierarchy information and the impact of corporate governance mechanisms', The Accounting Review, 85: 1375-1410.

Wallace, P. 'Accounting standards setting and implementation issues', paper presented at the ICAEW 2011 Information for Better Markets Conference on Accounting for Financial Instruments: Everybody’s Problem?, London, December 2011.

Wang, J. (2005) 'The Research on environmental constraints to accounting internationalism, strategy selection, and its effectiveness: Empirical evidence from Non-Monetary Exchange standard', Management World (in Chinese), 3: 15-22.

Xiao, Z., Weetman, P. and Sun, M. L. (2004) 'Political influence and co-existence of a uniform accounting system and accounting standards in China', Abacus, 40: 193-218.

Xiao, Z., Zhang, Y. and Xie, Z. (2000) 'The making of independent auditing standards in China', Accounting Horizons, 14: 69-89.

Zeff, S. (2007) 'Some obstacles to global financial reporting comparability and convergence at a high level of quality', The British Accounting Review, 39: 290-302.

Zhang, Y., Andrew, J. and Rudkin, K. (2012) 'Accounting as an instrument of neoliberalisation? Exploring the adoption of fair value accounting in China', Accounting, Auditing \& Accountability Journal, 25: 1266-1289. 